\title{
TESTE DE POLARIZAÇÃO FLUORESCENTE NA DETECÇÃO DE ANTICORPOS CONTRA Brucella abortus EM BEZERRAS DA RAÇA TABAPUÃ VACINADAS COM A AMOSTRA B19
}

\author{
(FLUORESCENCE POLARIZATION ASSAY FOR DETECTION OF ANTIBODIES AGAINST \\ Brucella abortus IN TABAPUÃ HEIFERS VACCINATED WITH B19 STRAIN)
}

\section{T. M. BLANKENHEIM ${ }^{1}$, R. B. M. BARTOLI ${ }^{2}$, G. C. P. SILVA ${ }^{1}$, R. MASSA ${ }^{1}$, D. B. SOUZA ${ }^{2}$, L. A. MATHIAS ${ }^{4}$}

A brucelose é uma antropozoonose infectocontagiosa de evolução crônica e distribuição mundial que causa sérios prejuízos econômicos. Na tentativa de controlar e erradicar a doença no país, foi criado um Programa Nacional que visa a vacinação de bezerras com a cepa B19 de Brucella abortus e diagnóstico para identificação de animais infectados. Para o diagnóstico sorológico, existe um amplo número de testes, entre eles o teste de polarização fluorescente (TPF), recentemente validado no Brasil e que vem se mostrando uma grande ferramenta para diferenciar animais vacinados com persistência de anticorpos daqueles naturalmente infectados. O objetivo deste estudo foi acompanhar a resposta sorológica de bezerras da raça Tabapuã à vacinação com a cepa B19 de Brucella abortus pelo TPF em comparação com os demais testes preconizados pelo Programa Nacional. Foram selecionadas 72 bezerras da raça Tabapuã com idade de vacinação. Os animais foram vacinados por via subcutânea na dose padrão recomendada. Amostras de sangue das bezerras foram obtidas imediatamente antes da vacinação e, 30, 60, 90, 120, 150, 180, 210, 240, 270, 300 e 330 dias. Para o diagnóstico foram utilizados a prova de antígeno acidificado tamponado (AAT), a combinação da prova de soroaglutinação lenta em tubos com a prova de 2-mercaptoetanol $(2 \mathrm{Me})$, a reação de fixação de complemento (RFC) e o teste de polarização fluorescente (TPF). Os 72 animais testados apresentaram-se negativos em todos os testes sorológicos realizados nas amostras de soro obtidos imediatamente antes da vacinação. Aos 30 dias de vacinação, o TPF apresentou especificidade variando de $15,71 \%$ a $44,29 \%$, conforme o critério de interpretação, contudo, nesta mesma ocasião, a concordância entre os resultados do TPF e os demais testes variou de fraca a regular. Aos 180 dias de vacinação, observou-se especificidade de $58,06 \%$ no AAT, $64,52 \%$ no $2-\mathrm{Me}, 64,52 \%$ na RFC e variando entre $35,48 \%$ e $74,19 \%$ no TPF dependendo do critério utilizado para a interpretação. Aos 240 dias de vacinação, o TPF foi o primeiro teste a proporcionar resultado negativo em todas as amostras. Desse modo, o TPF apresentou, em comparação aos outros testes, maior capacidade de discriminação dos títulos de anticorpos vacinais logo após a vacinação.

\footnotetext{
1 Doutoranda (o) - Departamento de Medicina Veterinária Preventiva e Reprodução Animal, FCAV - UNESP, Jaboticabal, Via de Acesso Prof. Paulo Donato Castellani, s/nº, CEP: 14884-900, Jaboticabal, SP. *tmbvet@ gmail.com

2 Doutor (a) - Laboratório de Sanidade Animal, Universidade Federal de Goiás - UFG, Jataí, GO.

3 Docente orientador - Departamento de Medicina Veterinária Preventiva e Reprodução Animal, FCAV - UNESP, Jaboticabal
} 